\title{
A Confluence of New Technology and the Right to Water: Experience and Potential from South Africa's Constitution and Commons
}

\begin{abstract}
South Africa's groundbreaking constitution explicitly confers a right of access to sufficient water (section 27). But the country is officially 'water-stressed' and around $10 \%$ of the population still has no access to on-site or off-site piped or tap water. It is evident that a disconnect exists between this right and the reality for many; however the reasons for the continuation of such discrepancies are not always clear. While barriers to sufficient water are myriad, one significant factor contributing to insufficient and unpredictable access to water is the high percentage of broken water pumps. Previous studies have reported that between $20 \%$ and $50 \%$ of all hand operated water pumps installed on the African continent are broken, or out of use. Monitoring and maintenance of pumps, which in South Africa is the responsibility of local municipalities is often ineffective, in part due to the distances between municipal centres and rural communities and the consequent costs of site visits, as well as breakdowns within the local bureaucratic system.

The emergence of new telemetry tools that can remotely monitor water applications constitutes a novel and cost-efficient alternative to undertaking regular sites visits. Sustainable, Appropriate, Low-cost Telemetry (SALT) systems are emerging that could be used to monitor the operational performance of water pumps, or a wide range of other field parameters, and to communicate this information swiftly and cheaply to water service providers, using SMS messages. Data on the performance of water pumps could also be made available to the public online. This is an example of how ICT can be used for Water Resources Management and environmental regulation, as well as in the governance of socio-economic rights: helping to optimize water allocation by improving communication and strengthening accountability.
\end{abstract}

Keywords: Commons, Human Rights, IWRM, Property, Telemetry.

\section{Introduction}

This paper explores the right to water within the South African Constitution (1996), its partial realisation in the country and the potential that new technology and a re-conception of property rights have to promote the goal of sufficient water for everyone in South Africa.

The emergence, and potential impacts, of Sustainable Appropriate Low-cost Telemetry (SALT) technologies are considered in relation to this Water Rights debate, and for promoting manifest equitable and sustainable water within South Africa, and beyond. We consider the limitations of Integrated Water Resources Management (IWRM) and the application of a rights-based approach to water via legislation and case law. We contend that early applications of the 'right to water' approach have revealed tensions between human rights and property. The merits of an alternative property paradigm are considered, by applying a 'commons' approach to water resource allocation. Ostrom's work in particular has served to highlight the potential of commons thinking to create sustainable frameworks for natural resource allocation (Ostrom: 1990, Harvey: 2011).

Drawing on empirical work in rural Kwa-Zulu Natal, as well as early applications of SALT prototypes, this paper considers the real-life problems experienced by many South Africans regarding access to sufficient water. It explores the potential that SALT technologies may have to increase fulfillment of the right to water by improving the functioning of existing infrastructure and by enhancing freedom of information by allowing pump performance data to be disseminated in cost-effective and user-friendly forms to a variety of stakeholders, as discussed in section 10.2. It is hoped that this dual approach (offering water service providers improved monitoring information, and making this information publically available in creative and useful ways) could result in a more efficient, responsive and transparent 
system of water allocation.

\section{Context}

South Africa's constitution (1996) confers a right of access to sufficient water (section 27) and a right of access to information (section 32 - referred to as the right to know). But the country is officially 'water-stressed' and around $10 \%$ of the population has no access to onsite or off-site piped or tap water (General Household Survey 2010). For many, there are discrepancies between these rights and their reality. The reasons for the continuation of such inconsistencies are not always clear. While barriers to sufficient water are myriad, one significant factor contributing to insufficient and unpredictable access to water is the high percentage of broken water pumps. This problem is not just experienced within South Africa; as previous studies have reported that between $20 \%$ and $50 \%$ of all hand operated water pumps installed on the African continent are broken, or out of use (Engel et al., 2003; Moriarty et al., 2004; RWSN 2004). Monitoring and maintenance of such pumps, which in South Africa is the responsibility of local municipalities is often ineffective, in part due to the distances between municipal centres and rural communities and the consequent costs of site visits, as well as breakdowns within the local bureaucratic system. Malfunctioning pumps can be attributed to a wide range of factors including: limited access to spare parts; insufficient technical capacity within the user community; inappropriate project implementation and/or technology choice, limited post-construction monitoring and support from external agencies (Moriarty et al., 2004). When such pumps break down local communities often have to resort to using less protected water-sources, which may increase their exposure to a wide range of water-related diseases.

Robust project monitoring, where implemented, can help identify if, and when, such problems occur; but in a sector where stakeholder resources are often overstretched this process may be neglected. Traditional monitoring strategies can often require key stakeholders, such as local municipalities, to conduct regular site visits, which may be difficult to implement and demanding on both staff-time and resources. Whether it is entirely due to such practical difficulties, or other contributory issues it is evident that the amount of post construction monitoring undertaken within the sector is limited. Once again, this is not just a South African problem, as an extensive study of 400 remote water points within Peru, Bolivia and Ghana (Whittington et al, 2008) have indicated that over a three-year period more than $50 \%$ of the surveyed water point communities received no visit, assistance or training from external support agencies. The same study indicated that where post construction support to a user community was provided there was a positive impact on their water-point's operational performance.

\section{The emergence of new monitoring technologies}

\subsection{Telemetry for water-related applications}

Telemetry tools that allow the remote measurement and reporting of system performance are widely used within many industries and sectors across the globe (Curran \& Pluta, 2008; Chaudhri et al., 2010). The earliest telemetry systems transmitted information via cable (e.g. a telephone line, fibre optic cable or computer network). More recent systems have utilised wireless data transfer such as radio, and many modern telemetry systems now use SMS messages to send and receive performance data via cell phone networks. The advantages of the SMS-based approach are the comparatively low costs and wide coverage offered by cell-phone networks. Curran \& Pluta (2008) report that the new generation of soft drink vending machines utilise this form of telemetry to transmit sales and inventory data and report the machine's operational status.

In many countries, telemetry has become a valuable tool for water-related monitoring applications. Such examples include: the use of telemetry for the automation of water meter readings; for undertaking remote leak detection in the water distribution network; and for monitoring discharges into 'receiving water-courses' from combined sewer overflows. In 
many instances, monitored data is relayed in 'real time' directly from the field to a central data handling facility - thus enabling the responsible organisation to implement rapid intervention strategies to address any observed problems.

To date, the use of telemetry for monitoring water applications across Africa has been somewhat limited. Key barriers that may have hindered the implementation of telemetry in this context are:
i. a lack of necessary support infrastructure;
ii. $\quad$ high costs of monitoring equipment and associated telemetry technologies;
iii. a lack of awareness of the technology and of it's potential applications and benefits amongst local water practitioners

However, as described in the ensuing sections, recent developments and technological advances appear to be addressing each of these aforementioned obstacles.

\subsection{Improved cell phone network coverage}

There has been a rapid expansion in both cell phone ownership and network coverage across much of the globe. Since 2003 cell phone subscriptions have reportedly grown faster in Africa than in any other region (UNCTAD, 2009). A recent survey indicated that in South Africa $84 \%$ of the surveyed adult population owned a cell phone (Gallop, 2010). Cell phone ownership now encompasses members of the lowest social economic groupings (Heeks, 2008).

\subsection{Reduced equipment costs}

The recent growth in cell network coverage has corresponded with a sharp fall in cell phone costs. Similarly the cost of mobile telemetry equipment has significantly dropped in recent times. Early mobile telemetry applications would typically have been undertaken using a GSM enabled field data logger, costing in the order of a thousand US dollars or more. The recent emergence of smart-phone technologies, costing hundreds rather than thousands of US dollars, has introduced a cheaper alternative means of telemetry. Furthermore, an even cheaper approach might involve the novel application of a lower tier phone (US\$20-US\$30) with a hardware-software plug-in upgrade as described by Chaudhri et al. (2010). It is also worth considering that there are now a number of other similarly low-cost (US\$20-US\$30) micro-processer based options such as Rasberry Pi boards that could perform an equivalent function.

\subsection{Lack of awareness}

It is envisaged that such advances have paved the way for new monitoring applications for water projects within an African context. One such example, is the 'Field Level Operations Watch' (FLOW)' system (WFP, 2010) developed by the "Water for People' NGO (NonGovernmental Organisation). The FLOW tool was introduced in order to develop better longterm partnerships with local communities and to improve post-construction monitoring of water and sanitation projects. FLOW is a monitoring tool that highlights the operational status of a water point (e.g. whether a borehole/well is working, on the verge of disrepair, or broken). Data is uploaded on to the Internet from the field by local stakeholders via an Android smartphone 'app' (see Figure 1); this action subsequently updates the status report for these water or sanitation facilities which appear on a Google Maps (c) layer accessible from the NGOs website. 


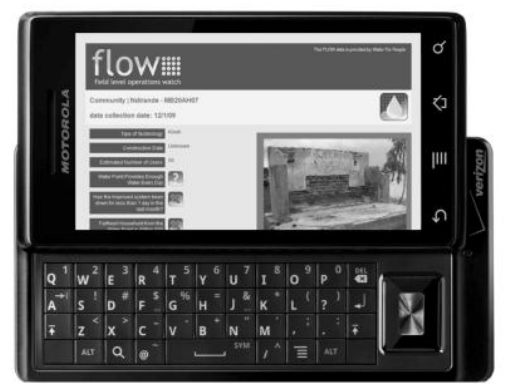

Figure. 1. FLOW status report app running on an Android smartphone (WFP, 2010)

The development of FLOW represents an interesting and timely attempt to address the problems associated with poor 'performance' monitoring of community water projects. The FLOW program also highlights a number of operational issues; and raises questions regarding the future direction of this type of approach. For example, the FLOW tool currently relies on information being manually inputted by local stakeholders via an Android smartphone. Hence, in order to rapidly identify an operational problem (i.e. such as a pump failure) the FLOW process still relies on the right people (i.e. those with the ability to use, and with access to a charged Android phone), being in the right place (i.e. near the broken water point), at the right time (i.e. immediately after the problem has occurred). However in practice this may be difficult to achieve, as Android phones are still relatively expensive to purchase; thus limiting the number of devices that can be supplied and used in the field. Secondly, many local stakeholders in such remote locations may lack the necessary infrastructure to keep these phones recharged. Furthermore, the current approach is open to human error that may lead to erroneous information being directly entered onto the FLOW system. It is therefore considered that the functionality of FLOW, or any similar monitoring systems, could be greatly enhanced by the implementation of low cost, self-powered, autonomous telemetry solutions that utilise cell networks to automatically report on the operational status of a communal water-point.

\subsection{Challenges and Appropriate solutions}

There are specific challenges associated with developing remote monitoring solutions for rural water pumps. For example, many such sites lack the electrical infrastructure required for recharging cell phones or other telemetry equipment. Alternative power sources may therefore be required, in order that this equipment may continue to operate over an extended period of time. PV solar cells and battery packs are the traditional power sources used in such circumstances. The merits of attaching a dynamo to the pump handle to harness renewable electrical power from the kinetic energy generated via the manual operation of the pump itself is another alternative that has been explored (Swan, 2012). Other obstacles that need to be addressed relate to: the lifespan and reliability of the telemetry equipment in the field; minimising the financial costs associated with both the device itself and the data generated; ensuring the security of the device at the water point; acceptability of this technology to both pump users and other key stakeholders; and evaluating how best to handle, and respond to the data conveyed from the site. For further discussion of these issues see Swan (2011) and Thomson et al. (2012).

It is therefore considered that appropriate telemetry devices should be autonomous, simple, cheap, robust, secure, and ideally recharged by a renewable power source in order to be effective and sustainable in this context. On-going studies are seeking to develop technically viable solutions to these challenges (Swan, 2011; Thomson et al., 2012; Charity:Water, 2013). The ensuing paragraphs briefly outline one such attempt to develop appropriate solutions to some of these problems. 
It should be noted that the complexity, costs, and power requirements of any given telemetry solution are all significantly impacted by the 'field parameter/s' being measured; and specifically the type, number, frequency and duration of readings to be taken. Simplifying the type and nature of these 'field parameter' readings should help moderate the complexity and costs of the remote telemetry equipment required to perform the task. Similarly, minimising the number of readings to be taken will in turn help reduce the unit's power demand.

In order to assess whether a water pump has, or is just about to malfunction, there are many different monitoring techniques that might be employed. For example, 'pumped' flow rates could be measured in near 'real-time' and this data relayed onto the Internet via cellular networks. Alarms could be triggered whenever preset minimum levels of usage fail to be achieved for a defined period of time (e.g. no recorded flow rates from a given pump over a period of say 2 days might be a strong indication that the pump has malfunctioned). This 'real-time measurement' approach, although technically possible and commonly used in other contexts, would require a high frequency of readings, a relatively high power demand and generate a relatively high level of data traffic. As such, this level of observation might be deemed inappropriate within a rural South African context, on the basis of both cost and complexity. It is worth considering that less complex telemetry approaches may prove more appropriate for such applications. One such approach is the subject of lab-based research, which is seeking to demonstrate the implementation of a prototype device for monitoring the operational status of a case-study water pump (shown in Figure 2).
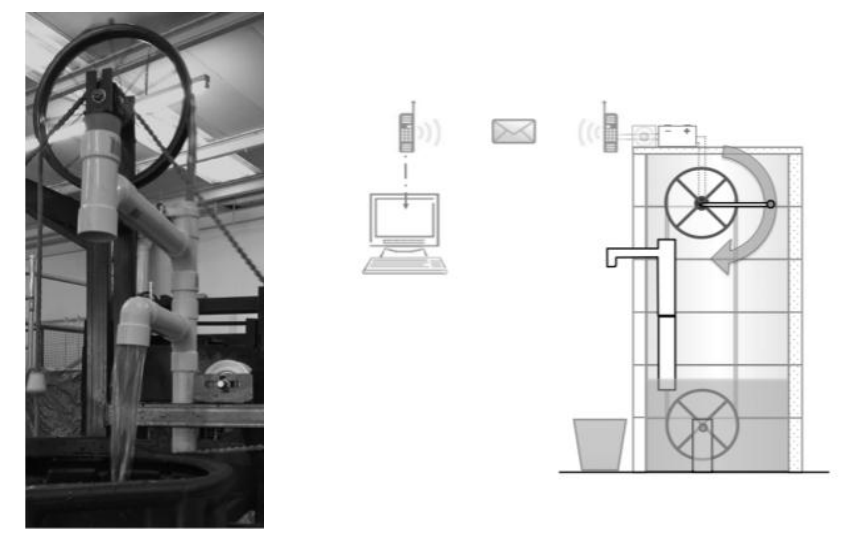

Fig. 2. Photo \& schematic of lab mock-up of elephant pump

The lab facility is currently being used to develop a novel system that utilises a dynamo, attached to the pump's handle, to act as the system's power source. This dynamo generates an electrical charge, whenever the pump operator turns the handle, which is then used to top up the system's batteries. Remotely monitoring changes in this battery level can provide a simple indication of the operational status of the elephant pump itself. For instance, if the pump breaks down in the field - it is anticipated that the frequency at which the handle is turned will subsequently diminish; which in turn will mean that the dynamo will not charge, causing the battery level to significantly drop - hence indicating that there is a problem.

These problems are detected by simple protocols used to monitor voltage levels stored in the battery, and are performed by a GSM enabled microprocessor. Figure 3 shows the basic rationale of this approach, and how it can be applied to generate both simple 'failure' alerts and regular 'operation' reports. 


\section{Simple 'failure' alerts:}

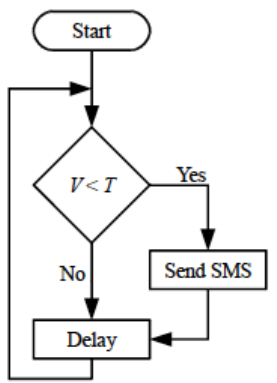

Regular 'operational' reports:

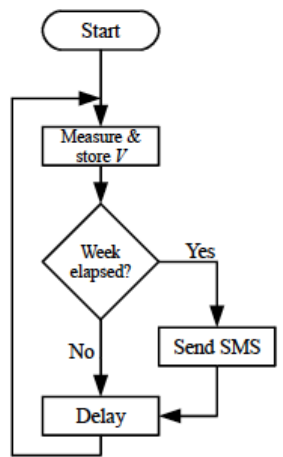

Fig. 3. Systems Diagrams for GSM enabled microprocessor remote monitor of battery voltage (recharged by dynamo on pump handle)

Simple 'failure' alerts - The system starts up and measures the voltage of the rechargeable battery. If this voltage, $V$, has dropped below a defined threshold, $T$, then an SMS message is sent to alert the base station that the pump has fallen into disuse. If the voltage has not fallen below the threshold, no action is taken. The system then goes into low power mode and waits for a period of time (e.g. a day, before waking up and repeating the process).

Regular 'operational' reports - The system starts up and measures the voltage of the rechargeable battery. It stores this voltage measurement in it's internal memory. If the reporting period (e.g. one week) has elapsed since the system last reported it sends an SMS message containing the voltage measurements from the past week. The system goes into low power mode and waits for 24 hours.

Simple monitoring protocols, such as these, require a much lower frequency and duration of 'field parameter readings than the 'real time' approach described previously. This in turn reduces the complexity and cost of the remote telemetry equipment required to perform the task. Similarly, minimising the number of readings being taken can reduce the unit's power demand. Further work is still required to test and evaluate the reliability, security and stakeholder acceptability of this method. But this work is ongoing, and progress is being made.

The aforementioned demonstration project, and other on-going studies (Thomson et al., 2012; Charity:Water, 2013) indicate that the technical challenges to remotely monitoring water pumps are continuing to be addressed. At this juncture, it would seem appropriate to consider the potential merits of applying these approaches for improving the "right to water" in South Africa, and beyond. 


\section{The Right to Water}

Access to sufficient water is a basic requirement for life. Although it is not mentioned explicitly as a human right in the Universal Declaration of Human Rights (UDHR, 1948) nor the International Covenant on Economic Social and Cultural Rights (ICESCR, 1966), access to sufficient water has progressively been recognised internationally as a human right since the 1977 UN Water Conference in Mar del Plata. In 2002, the General Comment No. 15, issued by the Committee on Economic, Social and Cultural Rights re-emphasised water as a prerequisite for the realisation of other human rights and restated that access to water was itself a human right. In July 2010, the UN General Assembly adopted a resolution recognising access to clean water and sanitation as a human right (UN GA10967 Adopted 28 July 2010.), further entrenching access to sufficient water as an internationally accepted human right to which the obligations of States party to the ICESCR apply.

In South Africa, the locus of this paper, access to sufficient water is an explicit right in the Constitution (s.27(1)(b) of the Constitution of the Republic of South Africa, 1996). Other Constitutional rights are related, directly or indirectly to this right, namely the right to equality (s.9), right to human dignity (s.10), right to life (s.11), property rights (s.25(8)), right of access to housing (s.26), rights of children (s.28), right to have access to courts (s.34), locus standi provisions (s.38), the Constitutional interpretation clause (s.39) and the environmental right (s.24).

In short, access to sufficient water is an internationally accepted and nationally protected right for all people in South Africa. Despite this, access to sufficient water is not a reality for many in the country. This paper considers the degree to which expressed acknowledgment of a right of access to sufficient water affects those people for whom access to sufficient water is problematic. The current and potential roles of IWRM are discussed within the limits of a rights-based discourse and questions are raised about the need to look beyond a paradigm of individual rights, to a commons approach to equitable water allocation.

\section{The Shape of Water Provision - Scarcity and Inequality}

Any discussion of water rights in South Africa must take into account that water is a scarce resource (Kidd, 2008). The increasing urban demands for water for domestic use jostle with demands from the industrial, mining and agricultural sectors. These demands are made in a country with an average annual rainfall less than the global average, and which falls unevenly across the country. Over a decade ago the South African Department of Water Affairs and Forestry (DWAF) warned of the unsustainable nature of water use:

With just $1200 \mathrm{KI}$ of available freshwater for each person each year... we are at the threshold of the internationally used definition of "water stress". Within a few years, population growth will take us below this level. South Africa already has less water per person than countries widely considered to be much drier, such as Namibia and Botswana. (DWAAF, 1997)

With the advent of majority rule in 1994 it was clear that a significant change in approach to water supply and water rights was necessary, based on the acceptance of two fundamental factors: the extreme inequality of water distribution (pre 1994), and the overall scarcity of water in terms of the total available to the country. A brief overview of the General Household Survey (GHS, 2010) gives the most recent picture of the nation's access to water for domestic use. The Eastern Cape currently has the lowest percentage of its population with access to on-site or off-site piped or tap water (72.8\% in 2007). Access in other provinces is as follows: Limpopo Province 83.4\%; KwaZulu-Natal 83.8\%, Mpumalanga; 89.1\%; Western Cape 99.5\%; Free State 96.8\%; Gauteng 98\%; Northern Cape $96 \%$ and North West $89.61 \%$. Of those who did receive piped water from a municipality, almost $25 \%$ experienced interruptions in their piped water supply at least once 
a month (GHS, 2010). Access to sufficient water remains a significant stumbling block to both socio-economic development and political stability (Russell, 2009).

These statistics only present a picture of people's access to water per se. They do not indicate the quantity of water people access or the reasons why they access it. Consequently the figure of $89.3 \%$ of the national population that has access to water does not indicate that the same percentage of people have access to sufficient water as section 27 of the Constitution stipulates. This issue has significant bearing not only on people's general level of health and well-being (Bond \& Dugard, 2007) but it has also been a key feature of the legal disputes over the Constitutional provisions. Sufficient water has been quantified variously at between 20 and 50 cubic litres per person per day (lpd). In South Africa the ANC's Reconstruction and Development Programme (RDP, 1994) set sufficient water at a minimum quota of $25 \mathrm{lpd}$, within 200 metres of a household. As the discussion below of the recent case of Mazibuko shows, defining sufficient water is problematic. But even using the RDP quota of sufficient water (25 lpd), a significant proportion of South Africans still do not have access even to this amount, 16 years into the democratic era. The recognition, promotion, protection and fulfilment of the right to sufficient water therefore remain crucial aims.

\section{Integrated Water Resources Management (IWRM) and South African law}

IWRM has been influential since the Dublin Statement (Dublin Principles, 1992). It has promoted a holistic approach to hydrological management, emphasising its ecological, economic and social implications. IWRM also recognises the right of all people to clean water and sanitation at an affordable price. This right, it is asserted, should be recognised first in all negotiations of water resources (Dublin Principles, 1992). But questions remain as to the specific objectives of IWRM and whether its emphasis on all relevant factors should remain procedural, or extend towards a more substantive agenda (Mitchell, 2005). Indeed, this tension mirrors contestation around the more wide ranging concept of sustainable development (Cooper \& French, 2012).

Nonetheless, the central conceptual theme of IWRM - that finite water resources are interdependent - leads some, including the authors, to the conclusion that decisions about water use must involve all users since they affect all users. Such an interconnected approach to water allocation, we believe, encourages long-term sustainability. It can also incentivise local self-regulation of water resources more effectively than central regulation and surveillance could.

IWRM thinking has provided the basis for water sector reform across the world, including shaping legislation in South Africa. Two Acts in particular have been promulgated in order to give effect to the right of access to sufficient water in the Constitution. The Water Services Act 108 of 1997 (WSA, 1997) is the principal legislative mechanism to actualize the obligations of the state. The WSA aims to provide inter alia the right of access to basic water supply and the right to basic sanitation necessary to secure sufficient water and an environment not harmful to human health or well-being' (WSA s.2). The Act further addresses the social and ecological purposes of water respectively, setting 'national standards and norms and standards for tariffs in respect of water services' and aiming 'to promote effective water resource management and conservation' (WSA ss.2(b) \& 2(j)). Basic water supply is defined in the WSA as 'the prescribed minimum standard of water supply services necessary for the reliable supply of a sufficient quantity and quality of water to households including informal households, to support life and personal hygiene' (WSA s.1). The Act sets the minimum quantity for basic water supply as 25 litres of potable water per person per day (25 lpd), or 6 kilolitres per household per month (WSA, Reg 1). This minimum quota is to be provided free of charge and is designated as Free Basic Water (FBW, 2001). 
Water services authorities, including municipalities, are charged with a duty 'to consumers or potential consumers in its area of jurisdiction to progressively ensure efficient, affordable, economical and sustainable access to water services' (WSA s.11). But there are no explicit provisions within the Act on how 'access' is to be achieved.

The National Water Act 36 (NWA,1998) is also important in implementing the Constitutional right to water. The chief aim of the Act is the protection of South Africa's water resources and as such the NWA addresses the ecological aspects of the right to water that underpin the primarily social aspects stressed in the WSA (Kotze, 2009). The WSA and the NWA were designed with the aim of facilitating access to sufficient water for all within the context of present and future ecological sustainability. The co-existence of these two Acts illustrates the importance of considering the socio-economic right to water within an environmental context that recognises and responds to competing claims for scarce water resources (including domestic, industrial, human, non-human, present and future claims). Indeed, the NWA has been described as the ecological 'Grundnorm' to facilitate access to water, setting the parameters within which sufficient water can be realised (Kotze, 2009). However, the Constitution makes no mention of prioritising either the right of access to sufficient water above the environment right or visa-versa. Similarly the NWA receives no explicit authority above that of the WSA. Therefore there is no legislative justification for limiting the social aspect of the right to water within the constraints of the NWA without acknowledging a corresponding need to view ecological priorities in light of the Constitutional obligation to provide access to sufficient water to every citizen. The imperative of providing sufficient water to citizens now, provides a pragmatic framework within which ecological aspects of, inter alia, sustainability, conservation, and biological diversity must be addressed (NWA s.2).

The right of access to sufficient water requires a definition of 'sufficiency' and 'access'. Neither term is defined in the Constitution, but as already discussed, sufficient water has been defined in the literature variously as between 20 and $50 \mathrm{lpd}$ and has received legislative definition as $25 \mathrm{lpd}$. Sufficiency has been described as being dependent on three factors, accessibility, adequate quality and adequate quantity (Scanlon et al, 2004). These factors include the five components of the human right to water as interpreted by the Committee on Economic, Social and Cultural Rights, namely that water must be sufficient, safe, acceptable, physically accessible and affordable (GC15, 2003; para 53).

Together, the Constitutional right of access to sufficient water and its promulgating legislation have framed the goal of realising access to sufficient water within a rights-based approach. Individuals have the right of access to sufficient water. This right should be progressively realised, according to the State's available resources and subject to certain qualifications. Measures to ensure economic imperatives, social development and environmental protection are included in these instruments, and recourse to restitution is available where individual rights are violated unreasonably (ultimately through litigation).

Consequently, discussion about access to sufficient water has been conducted largely using 'rights-talk'; framing problems and obligations within a paradigm of individual rights. The case of Mazibuko (outlined in Section 7) illustrates the limits of rights-talk in realising access to sufficient water. The case also highlights the courts' lack of consideration of sustainability, despite IWRM- influenced legislation. Indeed the interconnectedness of social, economic and environmental factors that IWRM emphasises seems to be recast here as three mutually exclusive camps playing a zero-sum game.

\section{Mazibuko and the Limits of Rights-Talk}

The case of Mazibuko was first heard in the Witswaterand High Court and was brought by a group of residents from Phiri in casu (Mazibuko, 2008). It challenged the legality of installing pre-payment water meters in the Phiri area of Soweto, near Johannesburg, in light of the Constitutional right to sufficient water. Installation was undertaken by the City of 
Johannesburg and its water company, Johannesburg Water in response to three problems: acute water losses in Soweto as a result of corroded pipes; an inaccurate tariff system (that meant more water was used than was predicted to be necessary); and a 'culture of nonpayment' for water services that had 'arisen originally as part of the resistance to apartheid local government' (Mazibuko, 2009).

The case examined the obligations of the City of Johannesburg and Johannesburg Water regarding access to water and the supply of free water for residents who could not afford to pay. In a first point, the operation of pre-payment in relation to the right to water was challenged. It was argued that since pre-payment water meters, by design, require users to pay for water in advance, access to sufficient water was curtailed if users could not afford to pre-pay. Such a situation was commonplace for Phiri residents and was raised as incompatible with the constitutional right to sufficient water.

In determining this ground, the High Court looked to GC15. Applying the General Comment, the court's view was that: "The State is under an obligation to provide the poor with the necessary water and water facilities on a non-discriminatory basis." Moreover, the progressive realisation of the Constitutional right of access to sufficient water meant that:

Retrogressive measures taken by the state are prohibited. If such retrogressive measures are taken, the onus is on the state to prove that such retrogressive measures are justified with reference to the totality of the rights provided for in the Covenant (ICESCR, 1966). The state is obliged to respect, protect and fulfil the right to water (para 37).

The installation of prepayment meters was held to be just such a retrogressive step, preventing residents from gaining access to sufficient water that they had previously enjoyed (before the prepayment meters, Phiri residents had access to a constant supply of water despite many accruing arrears as a result). The retrogressive step was therefore taken without adequate justification.

A second line of argument centred around the definition of sufficiency. The WSA's quantification of sufficient water at a minimum provision of $25 \mathrm{lpd}$ was directly challenged in this case on the basis that what is a sufficient quantity of water depends on the requirements of users in particular social circumstances. For instance people using waterborne sanitation require a greater volume of water to support life and personal hygiene than those using pit latrines.

In challenging the legality and validity of Regulation 3(b) of the WSA, which set the minimum water supply at $25 \mathrm{lpd}$ or 6 kilolitres per household, the applicants contended that the regulation was not only based on misconceptions about the amount of water necessary for residents in Phiri individually, but also about the average number of people living in each household. The 6 kilolitres minimum was based on a household of eight people, while it was submitted that the actual average for those residents was more than 16 people per household. As a result, it was contended that the regulation failed to provide 'sufficient water' as per the Constitution. The inflexibility of the regulation meant that it failed to distinguish between the needs of residents, for example, those residents with waterborne sanitation and those without, and consequently failed to provide a sufficient quantity of water to this group of residents (who used waterborne sanitation).

The decision of the High Court put great emphasis on the need to redress past injustices (as a result of apartheid policies) and the dire social and material state of many Phiri residents, described as 'poor, uneducated, unemployed and ravaged by HIVIAIDS'. Again the court looked to GC15 and held that, given the particular needs of the Phiri community (including their increased demand for water given their need to use waterborne sewerage) a volume of 
$50 \mathrm{lpd}$ would be a more appropriate quantification of sufficient water than the statutory $25 \mathrm{lpd}$ limit. Satisfied that the respondent could provide this increased amount 'without restraining its capacity on water and its financial resources' the High Court decided wholly in the applicants' favour, granting a declaratory order that Regulation 3(b) was unconstitutional and invalid, and ordering that $50 \mathrm{lpd}$ be provided to Phiri residents free of charge to those without the means to pay.

The City of Johannesburg and Johannesburg Water appealed to the South African Supreme Court of Appeal in February 2009 (Mazibuko, 2009). On that appeal, the quantity amounting to sufficient water for Phiri residents was reduced to $42 \mathrm{lpd}$. But the High Court's approach was otherwise upheld. The Supreme Court of Appeal addressed the questions of whether the appellants must provide Phiri residents with access to that quantity of water and whether the appellants must provide such access or access to a lesser quantity of water free of charge.

It was held that the Constitutional right to sufficient water was not a right of immediate fulfilment. Rather, this right, like those regarding housing, health care and food, are rights to be progressively realised, their progression being limited by lack of resources. Consequently, the right to sufficient water was not, in the judgment of the appeal court, an 'unqualified obligation'. However, the appellant's concern was not the quantity of water it may be obliged to provide, (the appellant did not contest that a volume of $42 \mathrm{lpd}$ was deliverable) but whether this quantity must be provided free of charge. Referring to General Comment 15 (UNCESCR, 2003) the appeal court accepted that the accessibility of water 'must be affordable for all'. Consequently the Constitutional right to sufficient water (revised to $42 \mathrm{lpd}$ ) had to be provided at an affordable price. Where residents could not afford to pay for this sufficient water and could prove this to the satisfaction of the water services authority, the appellants had an obligation to provide it free of charge in so far as this could reasonably be done having regard to the appellant's available resources. The City of Johannesburg and Johannesburg Water were directed to formulate a revised water policy accordingly.

Mazibuko in the High Court and Supreme Court of Appeal was heralded as an important milestone in socio-economic jurisprudence in South Africa (van Rensburg, 2008). It showed the courts' willingness to push the legislature towards concrete manifestations of Constitutional rights and not to allow the 'progressive realization' of these rights to result in unconstitutional policies. The impetus to promote and fulfill the right of access to sufficient water was clearly discernible in the acceptance of the need for sufficient water to be a quantity that promotes dignity and goes beyond the minimum of Free Basic Water already set. The potential implications of Mazibuko for people living in similar situations to the Phiri residents are significant. The judicial decisions reflect the courts' engagement with polycentric matters so as to realize socio-economic Constitutional rights more quickly and more explicitly than would otherwise be the case. But the environmental implications of Mazibuko are also significant, potentially doubling the demand for water from a significant portion of the population, in a 'water-stressed' country (Kidd, 2008).

However, in September 2009 the Phiri residents appealed to the Constitutional Court (unhappy with the Supreme Court of Appeal's order to reduce the amount water deemed to be sufficient from 50 to 42 lpd). This was the first time the Constitutional Court considered the interpretation of the right of access to sufficient water. The orders made by the High Court and Supreme Court of Appeal respectively were set aside. The Constitutional Court maintained that litigation regarding the positive obligations of socio-economic rights was an important element of government accountability. However, it was held that: 
The Constitution does not require government to be held to an impossible standard of perfection. Nor does it require courts to take over the tasks that in a democracy should properly be reserved for the democratic arms of government (paragraph 161).

The City's Free Basic Water policy was held not to be in conflict with section 27 of the Constitution or section 11 of the Water Services Act and the installation of pre-paid water meters was lawful. The court was satisfied that while the Free Basic Water Policy was flawed, it was consistent with the Constitutional right of access to sufficient water. This was particularly so since the City of Johannesburg had continually amended its Free Basic Water Policy during the course of the litigation.

Arguably, the Constitutional Court's decision reflects an impetus to maintain a clear separation of powers and to refrain from encroaching on matters of resource allocation, under the purview of the legislature and executive (Manqele, 2002). Also the reiteration that the Constitution does not require perfection imports a pragmatic approach to the right of access to sufficient water. Here the right is contextualized within broader government policy and its progressive realization is accepted where there is evidence of improving and continually revised policy. Such an approach is perhaps understandable in a country with limited resources and manifold social and economic problems, although it was not the approach that the High Court or the Court of Appeal felt the Law required. The Constitutional Court's decision emphasizes the tension at the heart of the justiciability of socio-economic rights: the pragmatism of progressive realization versus the necessity of immediate fulfillment. To those Phiri residents now denied access to a quantum of water commensurate with their needs and necessary for their dignity, their right to water rings hollow. The Constitutional Court's decision illustrates the limitations of using rights to achieve real access to sufficient water.

The social, economic and environmental considerations central to an IWRM approach to water allocation are visible to differing degrees in the courts' engagement with the Mazibuko case. But it is the social concerns of the Phiri residents pitched against the economic impetus of Johannesburg Water that are seen most clearly. The High Court and Supreme Court of Appeal afforded more weight to those social considerations of individual necessity for water and dignity; the Constitutional Court emphasized the nature of water as an economic good and the pragmatic limitations of progressive realization. The question of sustainability was raised at the Constitutional Court in relation to the ability of Johannesburg Water to provide a particular quantity of sufficient water per person. But this was distinctly a question of economic sustainability linked to the assumption that the water provider must be able to operate competitively. Concerns about protection and the potential ecological implications of doubling the quantum of sufficient water were conspicuous by their absence from the judgments of the High Court and Supreme Court of Appeal. Neither court mentioned the environmental right (particularly sustainable development) in section 24 of the Constitution. Despite environmental protection and sustainability featuring heavily in the legislation, these considerations appeared neither in the obiter or ratio of the Mazibuko judgments. Indeed the absence of environmental considerations is common to rights-talk in general as it is argued that individuals' rights claims are contested largely in isolation from the realities of resource scarcity. What is very clear is that the rights-based approach is problematic.

A liberal analysis of the limitations of rights tends to focus on flawed implementation. Sound ideas suffer from insufficient resources or poor application. But a more radical critique suggests that the limitations of using rights to achieve genuine socio-economic improvements lie in the way that rights (internationally accepted human rights or constitutional rights) give moral claims legal form. In so doing the moral claim is diluted, turning it into a technical legal problem and bureaucratizing away the imperative to meet the claim (Bond, 2009). When conceived as a legal problem, considerations like progressive 
realization, reasonableness and available resources become acceptable explanations for unmet claims. The moral claim that everyone should have access to the quantum of water required for dignified existence is immediately diminished because of the Constitution's limitations clause, which provides the State can restrict rights if it is doing so reasonably (section 36). Similarly the Constitution provides for the progressive realization of socioeconomic rights, but only within available resources. Lack of available resources is therefore a legitimate reason for unfulfilled rights, although the quantity and nature of available resources remain undisclosed. Such a critique does not deny that the right of access to sufficient water has helped reduce the number of people living with insufficient water in South Africa. The right has had positive substantive and normative effects and has underpinned significant legal victories (Residents of Bon Vista, 2002). But Pieterse (2007) and Bond (2009) assert that human rights generally and Constitutional rights specifically in South Africa concentrate on consciousness-raising and recognition of individual's right to necessities, rather than focusing on redistribution and reparation. Their potential for social transformation is therefore limited. We however would argue that there is another difficulty with the current rights-talk that is the operation of the right to property.

\section{The Problems of the Right to Property.}

Whilst the discussion about the rights-talk difficulties specifically in the Constitutional Court in South Africa produces a particular result in the object case for the right to water, we believe that there is a more general problem of the limitations of the rights-based approach. The inclusion of the right to water in the South African constitution is a truly ground-breaking development in the conversion of human rights from the international rhetoric to honest attempts to realise the rights for those who are fully dependent upon the Law to deliver its promises of justice and fairness. And we fully accept that all the Courts in the Mazibuko case were as committed to realising those fundamental rights and freedoms for the individuals involved. However, we consider that the problem that has to be overcome is one that is ingrained in the international community, ingrained in the fibre not of the South African attempts to realize the essential requirements for a dignified human life, but in the configuration and accepted values of international human rights.

At the heart of the impasse over the realization of the fundamental rights and freedoms promised in international human rights lie a number of tensions. We suggest that one significant difficulty in realising the potential of the rights is the dominant concept of property that is implicit within the international human rights jurisprudence. Taking the Universal Declaration of Human Rights as a starting point, there is a great tension created for the realisation of the social agenda within the international human rights canon. On the one hand, there are explicit rights to participate in the social and scientific advances in one's society, and from this a line of rights flow creating rights to the necessary elements of human well-being and dignity, for example, the right to healthcare, to housing, to education and the like. These form what could be described as the soft list of rights, because there is another, shorter list of hard rights in the human rights canon: the right to own property, including intellectual property.

In the international human rights agenda, arguably, this ownership right is much stronger, because it links to the question of the remaining acceptability of some forms of discrimination. Whereas the international canon of human rights law has accepted race and, to a large extent, gender as illegitimate discriminations, and is beginning to see age as an illegitimate form of discrimination, economic discrimination remains acceptable. Perhaps at the very edges of economic exclusion, where there is an appeal to justice in the need to respond to catastrophic natural disasters that plunge individuals into immediate and extraordinary poverty, claims are made that require a redistribution of economic resources for the well-being of individuals. However, in the normal daily run of poverty, economic discrimination is perfectly acceptable. The reality about making claims to the right to water is that they are appeals to soft rights, and they can be answered by the hard property appeal to 
economic discrimination. In this thinking the residents of Phiri are not denied their right, because 'if they can pay' is an acceptable qualification of their right (albeit that this is mitigated by the provision of a quantum of free basic water which is deemed sufficient, despite their experience to the contrary).

Indeed, this economic discrimination is arguably a necessary part of our international free market, where limited resources becomes a point of economic leverage. An individual might have a right to housing or to health care, but it is seen as an acceptable realisation of that right to enable that person to participate in a market and not to be excluded for reasons of his or her race, gender or age, but it is perfectly acceptable, in human rights thinking, for that individual to be told 'you cannot have this health care or accommodation because you cannot afford it'. And this is, in no small part, because of a number things that are forgotten about the conceptualisation of property.

First, 'property' is not a synonym for 'things'. Colloquially, property is about things. Property is a label, at one level, for different commodities; 'property' relates colloquially to the things that are valued in particular societies over time. So, land is a recurring 'thing' of property. In agrarian, artisan and industrialised societies, different commodities take on different cultural and economic importance and value. Today, for example, we speak about the information age', and different forms of information are commodified and become part of the owned world. Indeed, with the developments in modern biotechnology, even parts of human beings, animals and plants, have become independent commodities and part of the owned world. Today, ownership implies control and is closely related to monopoly or private ownership. This is a matter we will return to in a moment. Here the question is about what property is.

Property is not only the 'thing'. Indeed, property is not really the thing at all. Property is a description of the relationship of people about the thing. When we say that we have property in something, we are referring to a system of rights about our relationship to other people about that thing. We are saying to others, this is ours. As Beyleveld and Brownsword (2001) have noted, this is a particular sort of claim. We only have to be able to assert the provenance of our claim - that we purchased or made the thing - for the property to bind the world; the claim to property is to a right that binds the world. When we see a computer on an unattended desk, for example, we naturally think 'to whom does that belong?' We think the same, subconsciously, about the 'things' that we see on news reports and films from the opposite sides of the world; 'whose is that car?' 'to whom does that house belong?' We do not pause, in today's society, to ask whether a thing is owned, because we see it as part of the realm of commodities. We do not pause to think about the nature of the property that is or could be claimed. Our only real pause is in thinking how far the net is cast over commodities. Today we think about whether or not stem cells or human genes, or water can be owned, in the past we have considered whether or not human beings themselves can be the subject of property claims. This, however, does not mean that we cannot, or should not also question how far a property right extends in other respects.

Second, 'property' is a changing and changeable paradigm. Macpherson (1975) reminds us that the current paradigm within which we construct the concept of 'property' is not the only available concept that we have used or that we could use. Today, he reminds us, we operate with a private, industrial revolution based property. Fundamentally, we conceptualise property such that it is easily transferable between individuals; that property ownership is detached from social duties and is seen as part of a citizen's rights; the machinery of the state is used to enforce the property rights, which are, essentially, exclusive. We can develop complex layerings of rights-holdings over particular items of property (usually, the complexity is proportional to the perceived economic value of the commodity), but these are essentially created through the exchanged parts of the single exclusive right to the property. However, this is not the only way in which we have held property. Macpherson reminds us of the feudal system of property that preceded private, 
industrial revolution property. In the feudal system, property rights were much more attached to the individual and the individual's social duties; property rights were not citizenship rights, but were bestowed by the monarch and were held within the social hierarchy; property was not as easily transferable within this framework. Perhaps most significantly, property was not as exclusive. Within this system, and for social welfare purposes, common ownership (i.e. community rather than exclusively individual ownership) was important. Common land became a way of ensuring social security for some members of the community; collective access to the benefits of property was as important within the system as private or exclusive enjoyment.

This is not to advocate feudal society over modern industrial society. Macpherson is simply reminding us that the way that we conceptualise property today is not necessarily the only way to conceptualise property, or the only way that we have conceptualised property. He suggests that there are changes in our society that would suggest that two further conceptualisations of property, two periods of different paradigms, might be necessary and desirable. He indicates that the first move from private, industrial revolution property is to welfare rights as property. He sees that the next paradigm for property should be to make the right to work and the right to social security when one cannot work or has finished work the new 'things' that are owned by individuals. Once those rights are estabilised in society, he sees the need to make rights to political participation the subjects of property. These are, of course, Macpherson's next properties. The first resonates with Reich's 'new property' (Reich, 1964). This discourse, which was taking place in the 1960s and early 70s is, of course, before the oil crisis of the 1970s and then the grip of monetarism over international politics from the late 1970s onwards. The subject matter was, perhaps, very much a child of its time. What is not disputable, however, is the paradigmatic nature of property; the changeable nature of property in response to different socio-economic conditions. We moved from feudal to private property with the changing needs of industrialisation and market capitalism. The question is, today, do the new socio-economic needs require a change in the conceptualisation of property. Does the right to water, or perhaps more compellingly, the acknowledged need for water, require a fundamental reshaping of the property paradigms that operate internationally? Because here we are not seeking to suggest that the provision of water is something that can be achieved in isolation, it is part of a socio-economic system. We do argue, however, that the international property paradigm is at the heart of the system. This, in no small part, relates to the third observation about 'property'.

Third, 'property' is a moral issue. Morality is about the appropriateness of different actions of individuals towards other individuals. It is about being able to make a convincing justification for making particular choices that influence other people. Modern societies tend to limit the scope of morality, claiming that it relates to particular sorts of choices rather than others, for example, sexual morality rather than morality in international commodities trading or hedge fund management. However, morality is simply about justifying human choices and actions (Gewirth, 1978). Property is the relationship between individual human beings about things. It is about the claims that individuals make to bind each other about things. This then makes 'property' a moral issue, because the act of claiming the particular relationship to things against other individuals is a human action and therefore subject to morality.

When an individual says, 'this is mine', she is making an appeal to a particular sort of relationship to that property that she intends all other people to be bound by. She has to be able to justify that claim in terms of its morality. Generally, the underlying social response is to assume that ownership and property claims are necessarily moral, but this is questionable. When an individual's property claims have implications on others' well-being, then the requirement to be able to make the moral argument for that claim-making is imperative. When an individual stands next to a starving person holding two loaves, he has to be able to justify denying that starving person some of the bread 'because it is mine'. 
Indeed, 'because it is mine', or 'because I bought it', or, impliedly, 'because I deserve it and you do not' are hard moral claims to justify in the face of that person's starvation. And, of course, the need to question the morality of claims to property is not limited to the emergency situation, it is inherent in all acts of property-claiming. In this way, maintaining a simple private, industrial revolution property claim over access to water, or the means of supplying water, is a moral issue that requires robust justifications.

'Property binds the world'. The demand that property-claiming be subject to rigorous moral justification is not to place an unequal, or intolerable burden upon particular governments, local authorities, companies, or individuals. Because the concept of property is one that binds the world, it is universal and systemic. The requirement to make property a moral issue challenges all property ownership. The central point of the argument is that morality is not selective.

\section{A Return to the Commons}

We feel that a response to the inadequacy in the practical and conceptual basis for the right to water, and the inherently property based difficulty in human rights talk generally, lies in a property solution: a return to the 'commons'.

The commons emphasises the characteristics of water that make for a difficult fit within the private property paradigm. Not only is water essential for human life and for the health of all ecosystems; it has no substitute; it is inextricably linked with the hydrological cycle, which is itself connected with the particular geography of countries, regions and communities. Furthermore, water has important cultural and spiritual dimensions, which are also connected to the geographical location of particular communities. For each of these reasons, collective management of water by communities is not only appropriate, but necessary, if sustainable, appropriate resource management is to be achieved (Bakker, 2007). Furthermore, commons ideas have a long pedigree, having contributed to natural resource management since 'economic pre-history' (Ciriacy-Wantrup \& Bishop, 1975). Therefore the potential of a common property paradigm in relation to water must be seriously considered.

Whilst this might not herald a radical paradigm shift, we argue that it goes some way to meet the moral imperatives that underpin the right to water, most importantly by first ensuring full stakeholder participation, and second raising the soft right claim to water to the level of hard right property claims. Commons not only ensures that the individuals have a policy voice in ordering the competing claims to water, but it opens the question of the ownership of water rather than leaving it as an implied and unquestionable given in society.

'Commons' signify the idea that some resources belong to everyone - they are things subject to shared ownership - and that these common or community resources must be actively protected and managed for the good and benefit of all (On the Commons, 2012). This idea emphasises shared consumption in contrast to the dominant paradigm of individualised ownership and consumption, which saturates the preceding discussion of 'rights-talk'. Here the themes of interconnectivity and interdependence within IWRM, at least to some extent, are echoed. But unlike IWRM, a commons strategy avoids emphasising individual water rights, in favour of communal needs. This shift in focus may offer a more effective model of implementing sustainable water allocation, while avoiding the pitfalls of rights-talk inherent in the right to water. Further, by framing the right to water as a property issue, it moves it from the soft rights category into the hard, property rights category. A commons strategy would encourage decisions on water allocation to be made at the lowest appropriate level, involving all users to input into collective decisions that transcend a compromise of competing interests, in favour of communally 'owned' allocation decisions that best serve each community. 
A commons strategy, if innovatively applied to water allocation, may be able to transcend the limitations of the right of access to sufficient water, restating sufficient water as a moral claim, made corporately by and for people within their community. At the start of the paper we indicated that water allocation competes between domestic, local agriculture, industrial agriculture, and industrial uses. Setting water in common ownership would strengthen the domestic and local agricultural uses of water in relation to claims from industry. Equally, it would enable local users to understand the demands on their water from the different claimants, and enable the development of stakeholder generated water use plans. At the scale of local communities, this would require a transformation of people's roles from that of rights recipients, to a more active one as collective owners and decision-makers, better able to negotiate effectively within a forum of competing interests. Given the social, economic and environmental imperative for sustainability that any commons strategy must consider, IWRM too could find its functional imperative of sustainability rejuvenated beyond the limitations of rights-talk.

The wider application of small-scale manifestations of commons strategy, cannot be achieved easily. Ignoring problems of scale has its dangers. Indeed this is one of the significant flaws in Hardin's Malthusian predictions: taking a small-scale example of commoning - a village common, and applying it to a global problem (Hardin, 1968). But Elinor Ostrom's work in particular, shows how common property resources can be managed innovatively and appropriately in 'rich mixtures of public and private instrumentalities' (Ostrom, 1990). Likewise, romanticizing community control of resources must be avoided, since inequitable power relations can exist at small as well as large scale. Robust and transparent mechanisms are required, to address not just resource allocation, but also dispute resolution. Without such mechanisms the benefits of a commons approach over the current dominant mode, namely increased responsiveness and proximity of decisionmaking, risks being undermined by a loss of trust. Furthermore, it cannot be assumed that protection of environmental resources will be effectively achieved by commons approaches alone. For example Ostrom et al (1999) remind us that the management of large-scale resources such as fresh water in international basins depends on a multifaceted approach, including international co-operation and regulation. But, driven in part by the failure of rightstalk to effectively incorporate environmental protection and even to deliver resources to all individuals effectively, commons ideas are on the rise. Their success will depend, at least in part, on practical issues of responsibility (particularly regarding allocation of water resources and maintenance of infrastructure), information and communication; issues inherent in the development of SALT technologies.

\section{Connecting a rights/commons approach and SALT technology}

\subsection{External support and the role of low cost telemetry}

Having discussed the difficulties in the human rights based approach to access to water both at the level of domestic courts and from a highly theoretical approach to the relationship between human rights and concepts of property, and having suggested that the property difficulties underpinning the right to water, and many 'soft' rights could be addressed through a 'commons' approach to shared ownership of essential resources, we would like to end with a brief discussion of how low-cost telemetry might be used to help address the problem from a different, practical angle. At the beginning of the paper we identified how infrastructural failure has a major impact upon the provision of water. This practical measure could, in conjunction with other theoretical changes, also make an impact on the provision of water.

The effectiveness of some commons based community water ventures, or indeed, the provision of any water infrastructure, may be enhanced by appropriate input and assistance to improve communication and to catalyze effective community management. Often such support comes from water-related charities or government agencies, but the content of the 
support is the most important factor. As highlighted, recent advances in low cost telemetry could facilitate more targeted, and as a result, more appropriate capture and dissemination of information. Such new technologies could facilitate commons approaches to water allocation by providing community members, in addition to the other key stakeholders, with immediate and relevant information with which to address infrastructural problems swiftly. This would not directly address issues like lack of financial or technical resources. But seen in the wider context of moves towards a greater use of commons strategies, its potential to encourage and enfranchise local communities is significant.

\subsection{Information as empowerment}

As already discussed, SALT technology allows information on the performance of water pumps to be collected and sent by SMS. Here we suggest that the potential of SALT to strengthen the right to water and to empower people towards more effective and appropriate community management of water, lies in the questions of who receives this information and what they do with it.

Sending information on water performance to those directly involved in and responsible for pump maintenance could certainly be beneficial. Allowing pump performance to be remotely monitored could lead to quicker intervention and repairs than relying on periodic physical inspection and/or potentially delayed or unreliable reports from pump users. This may result in a cheaper, more efficient maintenance program and a more reliable water service. But this application of SALT would also create a closed loop of information, which could miss the transformative potential latent in this technology, if disseminated to a wider, but targeted group of stakeholders and interested parties.

Research conducted in the United States by Mehra \& Merkel (2004) shows the enfranchising effect of access to information on three minority and/or marginalized communities. In each of these groups access to information was identified as not only assistive in accessing resources and improving skills (including literacy, as identified in one group), but it also had positive (in some cases profound) effects on people's sense of self, sense of community and interconnectivity, as well as their physical, emotional and intellectual health. Of particular importance to our discussion of the empowering potential of SALT technology for water users, the groups in Mehra \& Merkel's study said that access to information that was meaningful to them actually empowered them to act as decision makers, rather than passive recipients. While this is just one example, the parallels are obvious. 


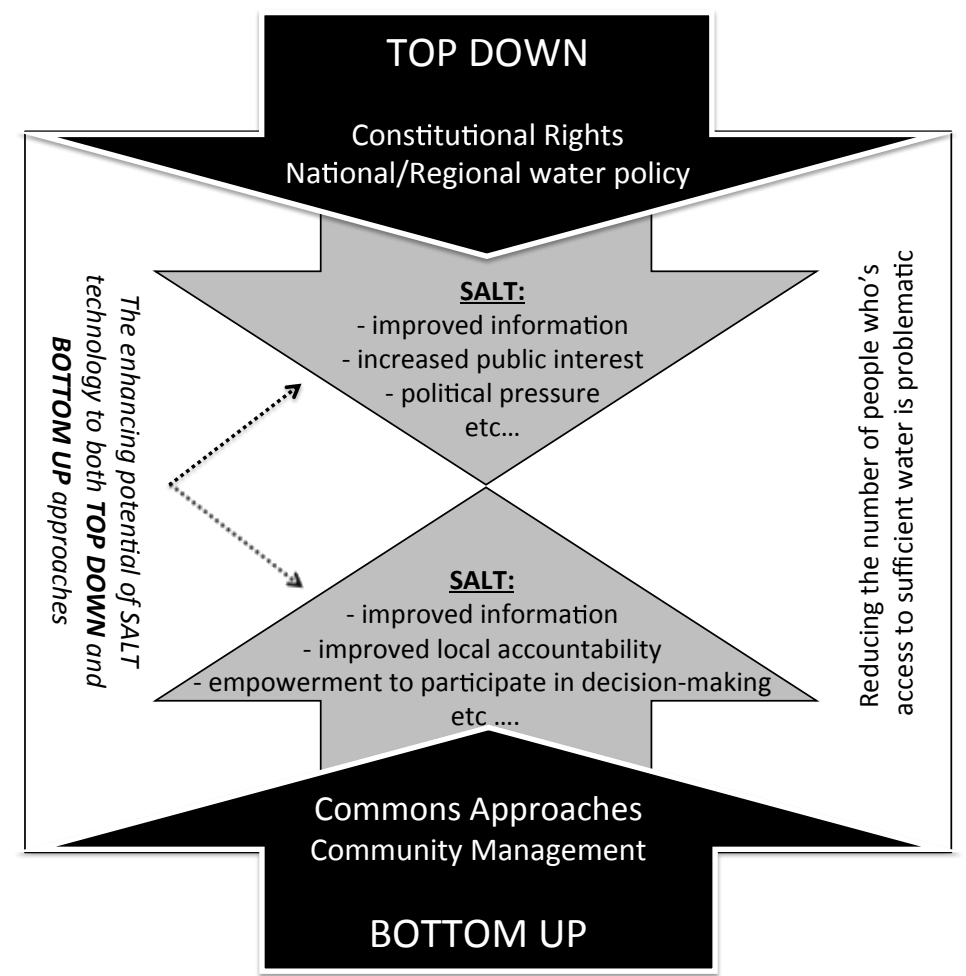

Fig. 3. Potential links between both 'rights based' and 'commons type' approaches and SALT technologies

There are a variety of ways in which both the 'rights based' and 'commons type' approaches to water resources might potentially be enhanced by the application of SALT type technologies (illustrated in Figure 3). In this brave new-media world we are keen not to be prescriptive about the particular form(s) that water-related performance information should be presented in (there already exists a host of creative infographics possibilities) or on (whether accessed on mobile phones, smart phones, tablets, computers etc.). Neither do we want to restrict imagination about the number of people or groups who could use this information positively, to help realize the goal of access to sufficient water for everyone. But we suggest that in addition to those stakeholders directly responsible for pump maintenance, there is scope for pump performance information to be used by water users themselves, by local community organisations and wider civil society, by NGOs, by local and national media and even by politicians in ways that focus attention and resources on what is an essential daily need and fundamental right. Moves towards greater community management of water resources would be assisted by accurate, accessible information. While at the other end of the scale, regional or national water policy could be contrasted with and informed by such prescient information. Indeed, such a generous but responsible dissemination of information mirrors the commons approaches to water considered above, creating an information commons which enhances the right to water by enfranchising stakeholders and accurately informing policy and public and political pressure towards sustained improvement.

Clearly, even within the shared stakeholder environment of commons, imposing an externally developed technology in communities produces very great problems. The development of low cost telemetry solutions should be undertaken in conjunction with local communities and water providers, however they are constituted. Furthermore, pump construction, maintenance and operation obviously involve issues of law (both public and private). Indeed, increased efficiency in monitoring pumps is important in realising the Constitutional rights to water discussed above (i.e. helping to avoid situations where broken pumps which previously provided water to communities are judged as retrogressive steps in the application of the right to water), and the availability of water was one of the problems 
identified by the courts. That said, an appreciation of the confluence of the broader social factors is essential in order to gauge the impact that new monitoring technologies could have within 'real-life' contexts.

To this end, formal existing relationships between water-pump users and service providers need to be investigated (as well as the less formal, but no less developed, interaction of users as community members, neighbours etc.) in order to help determine in what ways SALT could impact each stake-holder and how, where and by whom the telemetric information generated could be utilized to best effect. This information underpins any consideration of the institutional arrangements within which stakeholders might be represented, be that commons or public utility models of ownership and provision.

\section{References}

Bakker, K. (2007), 'The 'Commons' Versus the 'Commodity': Alter-globalization, Antiprivatisation and the Human Right to Water in the Global South' 39(3) Antipode (2007) 441.

Beyleveld, D. and Brownsword, R. (2001) Human Dignity in Bioethics and Biolaw Oxford: Oxford University Press. pp. 171-194

Bond, P \& Dugard, J, (2007), 'Water, Human Rights and Social Conflict: South African Experiences', 2007(1) Law, Social Justice \& Global Development Journal (LGD).

Bond, P. (2009) 'South Africa's rights culture of water consumption: Breaking out of the liberal box and into the commons?', 2009, Draft paper, presented at Syracuse conference, Cape Town, Feburary (2010). 12.

Chaudhri R., Borriello G., Thies W (2010), FoneAstra:making mobile phones smarter, Proceedings of the 4th ACM Workshop on Networked Systems for Developing Regions, p.15, June 15-15, 2010, San Francisco, California

Charity:Water (2012), A brand new technology supported by Google, Charity:Water Log website, Updated December 4, 2012, http://www.charitywater.org/blog/google-impactaward/, Accessed January 2013

Ciriacy-Wantrup, S.V \& Bishop, R.C. (1975) 'Common Property as a Concept in Natural Resources Policy', Natural Resources Journal, Vol. 15 p. 713

Cooper, N. and French, D. (2012), 'The Right to Water in South Africa: Constitutional Managerialism and a Call for Pluralism', Natural Resources and the Green Economy: Redefining the challenges for people, states and corporations. (Brill 2012).

Curran I., Pluta, S. (2008) Overview of machine and telematics water event, 2008 6th Institution of Engineering and Technology, Coventry, 22-23 April, ISBN: 978-0-86341-911-9

DWAAF, (1997) Department of Water Affairs and Forestry White Paper on a National Water Policy for South Africa (April 1997).

Dublin Principles (1992), The Dublin statement on water and sustainable development. In International conference on water and the environment, $<$ http://acuiferoguaranirrii.comuv.com/Archivos/DUBLIN.doc> (Accessed 2013)

Engel, S., Iskandarani, M. and Useche, M. (2003) Improved water supply in the Ghanaian Volta Basin: Who uses it and who participates in community decision making., Conference 
of the International Association of Agricultural Economists (IAAE), Durban, South Africa, August 2003.

FBW (2001), Free Basic Water Programme 2001. www.dwaf.gov.za/dir ws/fbw/. (Accessed July 2013).

Gallop (2011), Mobile Phone Access Varies Widely in Sub-Saharan Africa, Gallop website, Updated Friday, January 27, 2012,

http://www.gallup.com/poll/149519/mobile-phone-access-varies-widely-sub-saharan-

africa.aspx, Accessed January 2012

GHS (2010), General Household Survey, South African Government website, www.statssa.gov.za/publications/P0318/P0318June2010.pdf. (Accessed: July 2013)

Gerwirth, A. (1978) Reason and Morality, University of Chicago, Chicago \& London.

Hardin, G. (1968). 'The Tragedy of the Commons.' Science, Vol. 162

Harvey, D. (2011),'The Future of the Commons', Radical History Review, 109, p. 104.

Heeks, Richard (2008). "ICT4D 2.0: The Next Phase of Applying ICT for International Development". IEEE Computer 41(6): 26-33. doi:10.1109/MC.2008.192.

ICESCR, (1966), International Covenant on Economic, Social and Cultural Rights, adopted 16 Dec 1966, 993 U.N.T.S. 3 (entered into force 3 Jan. 1976), G.A. Res. 2200 (XXI), 21 U.N. GAOR Supp. (No. 16) at 49, U.N. Doc. A/6316 (1966).

Kidd, M. Environmental Law (2008), Juta \& Co. Ltd., Cape Town. p. 64.

Kotze, L. (2009), 'Access to Water in South Africa: Constitutional Perspectives from a Developing Country', Ymparistojuridiikka, 1/2009 s. 70-106. p. 78.

Macpherson, C. B. (1975) "Capitalism and the Changing Concept of Property", in Kamenka and Neale, eds. Feudalism, Capitalism and Beyond (London: Edward Arnold), 104-124.

Manqele V Durban Transitional Metropolitan Council 2002 (6) SA 423 (D\&CLD)

Mazibuko and others v City of Johannesburg and others (2008) (Centre on Housing Rights \& Evictions as amicus curiae) [2008] JOL 21829 (W).

Mazibuko and others v City of Johannesburg and others (2009]) JOL 24351 (CC).

Michael Kidd, Environmental Law, 2008, Juta \& Co. Ltd., Cape Town. p. 64.

Mehra, Bharat, Merkel, Cecelia and Bishop, A.P, "The Internet for Empowerment of Minority and Marginalized Users", New Media \& Society, 2004.

Available at: http://nms.sagepub.com/content/6/6/781 . Accessed January 2014.

Mitchell, B. (2005). Integrated water resources management, institutional arrangements, and land use planning. Environment and Planning 37: 1335-1352.

Moriarty, Patrick; Butterworth, John; van Koppen, Barbara (2004). Beyond Domestic: Case studies on poverty and productive uses of water at the household level. Delft, the Netherlands, IRC International Water and Sanitation Centre. (Technical Paper Series; no. 41). ISBN 90-6687-044-3 
NWA (1998), National Water Act, 36 of 1998: Available at:

http://www.info.gov.za/view/DownloadFileAction?id=70693 (Accessed July 2013).

On the Commons: http://onthecommons.org/about (Accessed July 2013).

Ostrom, E. Governing the Commons: The Evolution of Institutions for Collective Action, Cambridge: Cambridge University Press, 1990). p. 182.

Ostrom, E., Burger, J., Field, C. B., Norgaard, R. B., \& Policansky, D. (1999). Revisiting the commons: local lessons, global challenges. science, 284(5412), 278-282.

Pieterse, M. (2007). 'Eating Socio-economic Rights: The Usefulness of Rights Talk in Alleviating Social Hardship Revisited.' Human Right Quarterly, 29. Pp. 796-822.

Reich, C.A. (1964) “The New Property” Yale Law Journal, 733-787.

RDP (1994). White paper on Reconstruction and Development, Parliament of the Republic of South Africa, Cape Town, 15 Nov 1994

$<$ http://www.info.gov.za/view/DownloadFileAction?id=70427> (Accessed 2013)

Republic of South Africa (1996) Constitution of the Republic of South Africa - as

subsequently amended, http://www.info.gov.za/documents/constitution/. Accessed February 2012.

Residents of Bon Vista Mansions v Southern Metropolitan Local Council [2002] JOL 9513 (W).

Russell, A. (2009), Bring Me My Machine Gun: The Battle for the Soul of South Africa, from Mandela to Zuma, Perseus Books, USA.

RWSN (2004) The Handpump. Network for Cost-Effective Technologies in Water Supply and Sanitation, SKAT, St. Gallen, Switzerland

Scanlon J, Cassar A and Nemes N, (2004), Water as a Human Right?, IUCN Environmental Policy and Law Paper No 51, Gland, Switzerland and Cambridge UK, 2004, p. 28.

Swan (2011), Low cost telemetry for water applications in rural Africa: A review, Proceedings 12th International WATERNET/WARFSA/GWP-SA Symposium. Maputo, Mozambique, 2628 October 2011

Thomson, P., Hope, R. and Foster,T. (2012) GSM-enabled remote monitoring of rural handpumps. Journal of Hydroinformatics, IWA Publishing May 2012, ISSN:1464-7141

UNCESCR (2003), General Comment 15, The right to water, (29th session, 2003), United Nations Committee on Economic, Social and Cultural Rights,U.N. Doc. E/C.12/2002/11 (2002), reprinted in Compilation of General Comments and General Recommendations Adopted by Human Rights Treaty Bodies, U.N. Doc. HRI/GEN/1/Rev.6 at 105 (2003). Paragraph 2. <http://www.unhcr.org/refworld/docid/4538838d11.html> (Accessed 2012)

UDHR, (1948), Universal Declaration of Human Rights, adopted 10 Dec. 1948, G.A. Res. 217A (III), 3 U.N. GAOR (Resolutions, part 1) at 71, U.N. Doc. A/810 (1948).

van Rensberg, L.J The Right of Access to Adequate Water: Discussion of Mazibuko v The City of Johannesburg [Case No 13865/06], Stellenbosch Law Review, 2008, 3. p. 434. 
WFP (2010) FLOW Field Level Operations Watch, Water for People website, http://www.waterforpeople.org/programs/fieldlevel-operations-watch.html, Accessed on Jan, 2013

WSA (1997), Water Services Act, Water Services Regulations, Regulation 3 (b) in GN R 509, Government Gazette of 8 June 2001.

Whittington, D., Davis, J., Prokopy, L., Komives, K., Thorsten, R., Lukacs, H., Bakalian, A. and Wakeman, W. (2008), How Well is the Demand-Driven, Community Management Model for Rural Water Supply Systems Doing? Brooks World Poverty Institute Working Paper No. 22.

UNCTAD (2009) Information Economy Report - Trends and Outlook in Turbulent Times, United Nations Publications, UNCTAD/IER/2009, Geneva, Switzerland. 